\title{
EFFECT OF DIETARY PROTEIN AND ENERGY LEVELS ON GROWTH AND HEALTH OF EARLY WEANED RABBITS
}

\author{
A. M., Orma: Tarek, I. Mobamed and Rania E. M. El-Sayed \\ Deph of Nutrtion \& Nutrittonal Deflclency Diseaser. \\ Faculty of Vetertnary Mesicine. Manooura Uníversily
}

\begin{abstract}
The present study was carried out to evalwate the effects of protein and energy lew els in the diets of early weaned rabblts on the growth performance and general health Two groups of growing New Zealand White rabbits (18 each weaned eather at 26 or 35 days old, each was subdivided into 3 subgroups, each of 6 kits. Three diets were formulated to contain three levels of cnude protein (16 \&18 and 19.2 with three levels of energy (2522, 2831 and $3008 \mathrm{kcal} \mathrm{DE} \mathrm{/} \mathrm{Kg} \mathrm{diet,} \mathrm{respectivehy).} \mathrm{Each} \mathrm{subgroup} \mathrm{of} \mathrm{rab}$ bits was assigned fandomily to one of the three diets from time of uneaning till end of the expertment 184 days age). Body weight of the rabbits and consumed diets were weekly recorded and the feed converston ratto was calculated as well 3 rabbits from each subgroup were staughtered at end of the experiment for deternination of car. cass traits. Bload samples were collected from the ear vein of the rabbits at end of experiment io separate sera for analyzing the total protein, albumin, cholesterol and total lipid.

The results rewealed that early weaned rabbits may need to feed diet containing $18 \% \mathrm{CP}$ and $2831 \mathrm{kcal} \mathrm{DE} / \mathrm{Kg}$ dlet for nearly 24 days afer weaning and then after the excess of dietary prateon and energy than the recominended levels would be not beneficial in achiesing more body development or uetght gain. Increasing the dietary protein level or the energy concentration of the diet would forrnutated for the late weaned (35 days) rabbits than the recommended levels is not adutsable, even more. feeding the high protein $(19.2 \%)$ high energy $(9008 \mathrm{kcal} D E / \mathrm{kg})$ levels resulted in negative effect ( low body wetght. Nither the age of weanting nor the dietary levels of $C P$ or DE affect the dressed carcass, body organs diver, kddney heart) or abdominal fat percentages. Also, proximate chemisal compositton of liver and leg muscles showed no significant differences due to levels of dictary CP \& DE or age of weaning. Results of serum metabolites deternination showed no specific trends.
\end{abstract}

\section{INTRODUCTTON}

Intenslve rearing systems are Increasingly used at present in commerelal rabblt farms.
They are assoeiated whth weaning at early ages to reduec parturition tnterval and to increase numerical productwity of rabbtt does. 
Earty ureaning of young rabblts hus been proposed as a mean of reducing does energy denclt by decreasing milk energy output and improving the boty condition of the doe and lts health status (Pascual, 2001: Gidenne and Fortun-Lamothe. 2002; XIccato et al., 2004). Also, carly weaning could reduce the incidence of digestive disorders and reduced pathogen transmission by limiting contacts between litters and does (Schlolaut. 1088). The growth of rabbits could be affected by weaning age. Troctno al. (2001) observed that early wcaned kdts showed a lower llve welght in comparison with rabblts weaned at 32 days of age. Similar results were reported by Ctdenne and Fortun- Lamothe (2001). The negative effert of early weaning on live wcight was also reported by others (Ferguson et al., 1897; Gdenne and Fortun-Lamothe, 2001: 2003; 2004; Gallots et al.; 2003. 2004). In addition, early weaning at 25 days of age decrcased growth rate (Rodriguez et 1.. 1981) and increased diarthed inckence (Lebas, 1093) when young rabbits were fed commercial fattening diets. Consequently, design of appropriate starter diets seems to be necessary to shorten lactation period and maintain Intestnal health and performance of young rabbits. A major constralnt in formulatIng these spectal diets is level of energy and prolein. as younger animals have a less developcd digesule system (Marounek et al., 1995; Bcapluello et al., 1909). As a consequence. Increases the amount of energy or proteln reaching the terminal tleum, might increasc mortality during the post-weaning period (Blat and Gidennt, 1098; Lebas et al., 1008).

The addition of fat to diets for rabblts could improve feed effelency (Santoma et al,
1987). However, there is a lack of truformation on the effects of fat addition to dhets on growth performance, body composition and carcass characteristics of growing rabbits. So, the purpose of this research was to investygate the Inluence of protein and energy levels and lat addition to fibrous diets on growth performance, dressed carcass percentage measurements, body chemical composttion of llver $\&$ leg muscles and serum levels or some metabolites of early weaned rabbits.

\section{MATERTALS AND METHODS \\ The experimental rabblt and mannge- ment :}

Thity six unweaned New Zealand White (NEW) kJts were drvided into 2 equal matn groups of 18 litters each. The first group was weaned at 26 days old and assigned as early weaned rabbits, and the second one or the litters was left with thelr dams untll 35 days of age and asslgned as the late weaned rabbits. The growing rabblts in both weaning ages were subdivided into three subgroups 6 kits each). These subgroups were randornty asstgned to the respective dietary treatments which differ in protein levels $(16,18$ or $19.2 \%$ CP) with different energy levels (2522. 2831 and $3008 \mathrm{kcal} \mathrm{DE} / \mathrm{Kg}$ dlet, respectivelyl, to malntain the ealorie $/$ proteln ratio nearly constant (rable 1). All rabblts were vacdnated agalnst smufles using Hemorrhagic Septlcema Vaccine and protected against paraslies usting Ivomec preparation $10.5 \mathrm{ml}$ subcutaneous).

The Htters were ralsed in a nat deck battery system with universal specibeation. Thach doecage was suppiled onth a metal nest-box, metal feeder and ntpple drinkers. The kindled litters remalned in their nests with thetr darns 
lor suckling and eating from birth till ume of weaning (etther at 26 or 35 days). Does and ltters were fed diet containing $17 \mathrm{CP} 96,2700$ kcal DE/ kg \& $11 \mathrm{CF} \%$. The weaned growing rabbuts were sexed, welghed and tattoced. Thenafter, the rabblts were removed into the growing batteries $175 \times 50 \times 35 \mathrm{em} / 2$ growing rabbltsl atcordting to thetr experimental feed. Ing treatment. The batterdes were placed in a windowed, naturally ventilated room. Expermental perdod extended for 12 weeks from mud of Octaber 2008 to mid of February 2009.

\section{Expertroental diets:}

Three experimental diets were rormulated. First diet (control) was formulated according to NRC (1977) recommendation guldes for" the nutrient requirements of growing rabblts to provide $16 \% \mathrm{CP}$ and $2522 \mathrm{Kcal} \mathrm{DE} / \mathrm{kg}$. The second diet provided $18 \% \mathrm{CP}$ and $2831 \mathrm{Keal}$ DE / $\mathrm{kg}$ and third det provided 19.2\% $\mathrm{CP}$ and $3008 \mathrm{Kcal} \mathrm{DE} / \mathrm{K}$. The expertmental diets supplemented with a mineral- vitamin premix to eover the requircd trace elements and vitamins for growing rabbits. The formulated diets were composed, mixed well and pelletized $(0.4 \mathrm{~mm})$ then kept in plastle bags till using. The ingredtents percentage and calculated ehemteal composution of the expertmental diets are presenled in table 1. The growing rabbuts were fed ad llbitum and water was avallable all the the. Experimental dlets were provided 2 thnes daily (8 AM and 4 PM) in estlmated amounts to avoid wasting.

Indices for evaluatlon of growth performances and serum metabolltes :

The rabbits were welghed at the first day after weanlng to oblain the average inltial body weight then the average body wisht and trady galn were weekly determined. The aver age feed consumption and feed eorverslon raUo per rabbit per week was calculated through out the expertmental pentod.

At the end of experiment, blond samples were colleeted from 4 rabbits from each experImental subgroup. Sera were obtalued by allowing blood samples to coagulate then centrifuged at $3000 \mathrm{rpm}$ for 15 minutes. The separated sera were frozen at $-20^{\circ} \mathrm{C}$ in deep freezer until used for determination of total protein (Kaplan et al, 1984), albumin (Douman et al., 1971), cholesterol (Allain et al., 1974) and total lipld (Zoliner et al., 1962).

\section{Carcase traits:}

At the end of expertment ( 84 days age), three rabbits from each expermental subgroup were randomly token. weighed and slaughtered to complete bleeding and rewelghed again. The rabbits from cach treatment were dressed, eviseerated and the dressed earcass of (Carcass weight / live weight $\times 100$ ). abdomlnal \{at, llver, kldneys and heart welghts and percent in relation to the live body welght were determined.

\section{Chemical analyols:}

Samples from experimental diets were taken for proximate ehemlcal determination of $\mathrm{CP}, \mathrm{CF}, \mathrm{EE}$ and ash. In addition, samples Irom internal organs (lwer and leg muscles) were taken for determination of $\mathrm{CP}, \mathrm{EE}$ and ash contents according to the conventional methods described by the A.O.A.C. (1890).

\section{Statlstical analyols:}

Obtalned data In the present work were statisucally analyzed for analysis of varance 
(ANOVA) and least signiflcant difference (LSD) as described by Snedecor and Cochran (1067).

\section{RESULTS \& DTSCUSSTON}

The data showed that feeding the early weaned rabblts (26 days) the high protelnhigh energy dlets $18 \% 19.2 \% \mathrm{CP}$ and 2831 \& $3008 \mathrm{kcal}[\mathrm{JE} / \mathrm{kg}$, respectlvely) significantly Improved LBW and BG (Tables 2 3) com pared to the rabbit led the normal recommended diet contalning $16 \% C P$ and 2522 $\mathrm{kcal} \mathrm{DE} / \mathrm{kg}$. The statistically significant increase in BW was continued till the 49 days of age. However, the growing rabbits weaned early at 26 days and led the djet containing $18 \% \mathrm{CP}$ had statistieally higher llve body welght (LBW) than those fed the $19.2 \% \mathrm{CP}$. dlet starting from the age of 49 days old till end of the experiment at 84 days. The datia for the early weaned rabbits led the higher protein diets $(19.2 \%$ CP) Indicaled that the excess In dietary proteln percentage (3.2\% CP) did not Improve BW development or BWG during the perlod from 49-84 days of age (Tables 2 . 3). The results showed that BWG for the rabbits group led the high protein diet (19,2\%) was lower than that reported for the rabbits group fed the recommended. low protein diet (16\% CIf in this pertod. The present results are in agreement with the fndings of Rexzorenova and Moroxcra (1880) and others that diet of growing rabblts should contain 16.5 to 18.5\% CP. Also, Sanchez et al. (1985) showed that Increasing the level of dletary CP to 19 or $20 \%$ lowered boty welght galn. Mowever, Raharjo et al. (1088) reported that feeding diets containing 16 or 21 o $\mathrm{CP}$ gave comparable (equal) growth performance. On the other hand Jacob ot al. (1002) led growing rabbits diets containing $14,16 \& 18 \% \mathrm{CP}$ and 2600 kcal DE/ $\mathrm{kg}$ and concluded that WG increased linearly with increasing $C P$ in diets and proteln requirement for maxtmum growth of rabbits 13 greater than that recommended by KRC (1977). Also, Oongont et al. (1893) reported that feeding $18.3 \%$ CP diet gave glgniflcaritly greater body weight than 16.82 23.32\%. On this concept. Zananty and Ahmed (2000) Indicated that live weight of NZW rabbits improved slgnificantly ( $p<0.05$ ) as dietary CP level increased up to $18.2 \%$.

In the late weaned rabblts ( 35 days), leedling the high proteln-high energy diets $18 \%$ and 19.2\% CF and 2831 \& $3008 \mathrm{kcal} \mathrm{DE} /$ $\mathrm{kg}$ did not inproved BW or BWG along with the experimental period. Unexpectedly, feeding the late weaned rabblts (35d) the diet containing the normal reeornmended proteln (16\%) and energy $(2522 \mathrm{kcal} / \mathrm{kg}$ statistically give the same results as those fed the high protein (18\% CP) and high energy (2831 kcal $\mathrm{DE} / \mathrm{kg}$ ) diet. Abdel Malak (2000) showed that LBWG of NZW growing rabbits tncreased by Increasing dietary $\mathrm{CP}$ levels but with no signiflcant differences hetween groups fed $16 \&$ $18 \% \mathrm{CP}$. Therelore, it could be concluded that the early weaned rabbits (at 26 days) may need to led diet contalning $1896 \mathrm{CP}$ for nearly 24 days following earty weaning (26 days) and the excess of protein in the diet would be not benefictal in achieving more body development or weight gann. Increasing the dietary protein level or the energy concentration of the diet would be formulated for the late weaned ( 35 d) rabblts than the normal necom. mended levels is not advisable, even more. feeding the high protein (19.2\%) high energy ( $300 \mathrm{kcal} \mathrm{DE} / \mathrm{kg})$ diet resulted in negative 
effect on growth. Similarly. Eeugler et al. (2000) who fed growing rabblts of 36 days old diets contalning 15,18 or $21 \% \mathrm{CP}$ and concluded that dict contalning $C P$ level less than 18\% showed the lowest growth rate as compared with other respectuve treat ments.

\section{Feed Intake and feed canverwlon ratlo:-}

Generally, the results concerning the weekly amount of feed intake of the rabblt groups weaned at 26 and 35 days of ages and fed the different experimental diets did not show speeffle trend (Table 4). The flurtuation recorded in the weekly amount of feed intake between the ditlerent rabbit groups in some weeks of the experiment can not be explained well. however. It might be a rellection of health status, difference in body weight development of rabult groups or encrgy concentration of the experimental diets. In splte of the fact that the amount of cumulative feed Intake is sta tistically the lowest $(5750$ and $4900 \mathrm{~g})$ in the rabbit groups weaned at 26 or 35 days, respectively and fed the high protein-high energy diets (19.2 \% CP). On the other hand, the rabbli groups fed $16 \% \mathrm{CP}$ and $2522 \mathrm{kcal} \mathrm{DE/}$ $\mathrm{kg}$ consumed higher amounts of tixc diet during the whole cxperdmental pertod $(6190$ and 5322 g) for the rabbit groups weaned at 26 and 35 days, respectuvely.

Fced converston ratios (FCP) were mostly better and slenificantiy less in the rabblt groups weaned at 26 days and led the high proteln high energy diets compared to the rabbit groups fed the recommended levels of $C P$ and DE (Table 5). It is of great importance to observe that feeding the late weaned rabbits (35 days) diets containing hither levels of elther CP (1B or $19.2 \%$ ) did not improve the FCR (Table 5). This finding indicated that increasing the $C P$ and $D E$ levelo In diets of the - late wcaned growing rabblt is not advisable and the recommended levels $116 \%$ CP \& 2522 kcal $D E / \mathrm{kg}$ are practically sufliclent for feedIng the NZW rabbtts under local condttions. However. increasing the $\mathrm{CP}$ and energy con tent (18\% $\mathrm{CP}$ and 2831 keal DE/ $\mathrm{kg}$ ) in the diet of the early weaned rabbits (26 days) Improved the dlet utilization represented in the tcrms of body weyht and FCR $(2468 \mathrm{~g}$ and 2.9.3)

\section{Proteln effletency ratlo (PER)}

It is clear that efficieney of proteln is markedly effective in the early weeks of growth especially in the kits weaned at 26 days of age. Also, the highest PER is recorded for the early weaned (26 d) rabbits fed the diet contalning $18 \% \mathrm{CP}(6.22)$. The potency of PER of the different diets decreased gradually with increasing of agc of the rabbits (Table 6) These Indings Indlcated that growing rabblts need some higher protein content (1996) in thetr dlet during the carly weeks of age (26-49 days).

Generally, feedlng the 18 CP det has the best PER value (1.92) In the early $(26$ d) weaned rabbits. The data also showed that feeding the recommended diet $116 \%$ CP 2522 kcal DE] has the best value of total PER In the late weaned rabbit groups (1.89 vs 1.64 or 1.45 for the 18 or $19.2 \%$ CP dlet respectlvely). This finding indicated that late weaned rabbits may do not need further increased in delary CP or energy than the recommonded levcls espectally in the late growung perlod lafter 42 days of agel. 
A. M., Orma; et al...

\section{Carcams tralts:}

The data showed that elther of dletary protein and energy lcuels or age of wearing of the kits had signuflcant impact on dressed carcasso. organs welght or percentage to live weight. On the other hand feeding the growing rabblt the high proteln- high energy diets (IB or 19,2 \% CP \& 2831 or $3008 \mathrm{kcal} \mathrm{DE} / \mathrm{kg}$, respectively) increased the fat percentage of dressed carcass rTable 6i. Tracino ot al. (2001) and Tumova al. (2006) concluded that age of weaning did not affect dressing percentage in growing rabbits at slaughtering. On the other hand Ayyat and Maral (1987) showed that feeding growing rabbits high energy diet Increased dresses carcass percentage.

Nether the age of weaning nor the dietary Ievels of $\mathrm{CP}$ or $\mathrm{DE}$ affect the dressed carcass. body organs (Iver. kidney \& heart) or abdominal fat percentages Thable 8;. Also, proxlmate chemical compostion of Hver and leg muscles showed no significant differenccs due to levels of dietary CP \& DE or age of weaning (Table 9). Results of serum metabolites determination showed no speciflc trends (Table 7). 
A. M., Orma; et al...

Table 1. Ingredients and calculated chemical composition of experimental diets.

\begin{tabular}{|c|c|c|c|}
\hline & \multicolumn{3}{|c|}{ Experimental diets } \\
\hline & I & II & III \\
\hline CP level & $16 \%$ & $18 \%$ & $19.2 \%$ \\
\hline DE (Kcal/Kg) & 2500 & 2812.5 & 9000 \\
\hline \multicolumn{4}{|l|}{ Ingredients } \\
\hline Corn, yellow & 20.75 & 16.75 & 13 \\
\hline Soybean meal & 21.0 & 26 & 31 \\
\hline Barseem hay & 19.39 & 20 & 17.75 \\
\hline Wheal bran & 16.5 & 20 & 17 \\
\hline Wheal straw & 15.81 & 8.5 & 9 \\
\hline Molasses & 30 & 2.0 & 2.0 \\
\hline Cotton seed oil & , & 3.5 & 7 \\
\hline Min. ard vit, Premix & 0.25 & 0.25 & 0.25 \\
\hline Lime stone & 1.1 & 1.2 & 1.2 \\
\hline Dicalcium phosphate & 1.1 & 0.8 & 0.8 \\
\hline Antitoxin & 0.1 & 0.1 & 0.1 \\
\hline Anticoccidia & 0.1 & 0.1 & 0.1 \\
\hline Charcoal & 0,2 & 0.2 & 0.2 \\
\hline Common salt & 0.5 & 0,5 & 0.5 \\
\hline Methionine & 0.2 & 0.1 & 0.1 \\
\hline \multicolumn{4}{|c|}{ Calculated chenical composition } \\
\hline$C P \%$ & 15.98 & 17,96 & 19.2 \\
\hline DE $\%$ & 2522 & 2831 & 3008 \\
\hline CF \% & 13.23 & 11.20 & 10.9 \\
\hline $\mathrm{Ca} \%$ & 0.35 & 0.36 & 0.36 \\
\hline$P \%$ & 0.47 & 0.53 & 0.53 \\
\hline Lysine $\%$ & 0.74 & 0.89 & 1.1 \\
\hline Methionine, eyslinc\% & 0.40 & 0.46 & 0.54 \\
\hline \multicolumn{4}{|c|}{ Analyzed chealeal composition } \\
\hline $\mathrm{CP} \%$ & 15.86 & 17.79 & 19.40 \\
\hline $\mathrm{CF} \%$ & 12.75 & 11.80 & 11.12 \\
\hline EE \% & 3.55 & 7.14 & 10.13 \\
\hline Ash \% & 11.06 & 10.91 & 9.50 \\
\hline
\end{tabular}

The inineral- vilanin premix provide per $\mathrm{kg}$ dict: vitanin $\mathrm{A}_{1} 12,000 \mathrm{IU}$; vitamin $\mathrm{D}, 2,500 \mathrm{IU}$; vitamin $\mathrm{E}, 12 \mathrm{mg}$, vitarnin $\mathrm{K}, 2.5 \mathrm{mg}$; vitamin $\mathrm{B} 1,1.2 \mathrm{mg}$; vitamin $\mathrm{B2}, 6 \mathrm{mg}$; pantotheric acid, 12 Ing: folic acid, $1.2 \mathrm{mg}$; niacin, $36 \mathrm{mg}$; pyridoxise, $2 \mathrm{mg}$; vitamin B12, $0.01 \mathrm{mg}$; biolin, $0.06 \mathrm{mg}$ : Choline, 100mg; iron, $36 \mathrm{mg}$; copper, $\$ \mathrm{mg}$ : manganese, $72 \mathrm{mg}$; zine, $60 \mathrm{mg}$, iodine, $0.45 \mathrm{mg}$; selenium, 0.12 ang. 
Table 2. Effects of dietary protein and energy levels on body weight development of the growing rabbits weaned at 26 and 35 days of age.

\begin{tabular}{|c|c|c|c|c|c|c|}
\hline \multirow[b]{3}{*}{ Dietary CP } & \multicolumn{5}{|c|}{ Weaning age, tay } & \\
\hline & \multicolumn{3}{|c|}{26} & \multicolumn{3}{|c|}{35} \\
\hline & 16 & 18 & 19.2 & 26 & 48 & 19.2 \\
\hline \multicolumn{7}{|l|}{ Agte day } \\
\hline 28 & $408 \pm 1028$ & $412 \pm 12.34$ & $408=9.87$ & - & 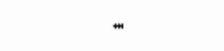 & - \\
\hline 30 & $546^{\circ} \pm 11.21$ & $600^{*}=10.15$ & $605^{*} \pm 7.27$ & - & + & - \\
\hline 3 & $706^{\circ} \pm 3097$ & $810^{b}=32.53$ & $820^{*}=21.50$ & $886^{2} \pm 15.15$ & $380^{2} \pm 10.00$ & $890^{\circ} \pm 1.4 .08$ \\
\hline 42 & $916^{6} \pm 4.35$ & $1053^{3} \pm 42.48$ & $1044^{\circ}+35.57$ & $1162^{x}=31.28$ & $1113^{ \pm} \pm 38.88$ & $1126^{2}+34,4$ \\
\hline 49 & $1177^{d}=7.73$ & $1299^{x} \pm 53.75$ & $1241^{1053.55}$ & $1346^{06}=51.14$ & 1 神 $10^{*}=29.06$ & $1367^{-10} \neq 66.79$ \\
\hline 56 & $1418^{4} \pm 82.53$ & $1540^{b} \pm 62.30$ & $1453^{6} \pm 89.32$ & $1630^{2} \pm 63.25$ & $1622^{*} \pm 38.42$ & $1576^{\circ} \# 67.35$ \\
\hline 63 & $1650^{\circ}=79.27$ & $1766^{5} \pm 634$ & $1658^{\circ} \pm 60.2$ & $1845^{\circ}=1.56$ & $1835^{3} \pm 48.89$ & $1762^{\circ}+37.44$ \\
\hline 30 & $1841^{5} \pm 89.3$ & $1978^{4}=80.86$ & $1845^{12}+689$ & $2087^{*}=86.3$ & $2050^{\circ} \div 479$ & $1940^{\circ}=42.43$ \\
\hline 77 & $2064=93.6$ & $2214^{* *} \pm 506$ & $2017^{*} \pm 59.2$ & $2282^{\circ} \pm 75$ & $2264^{*} \pm 66.9$ & $2118^{*}+27.7$ \\
\hline 8.4 & $2218^{b}=86.7$ & $2468^{\circ}=456$ & $2158^{\circ}=48.9$ & $2477^{\circ}: 875$ & $2487^{\circ} \pm 73.2$ & $229 !^{*}+68.4$ \\
\hline
\end{tabular}

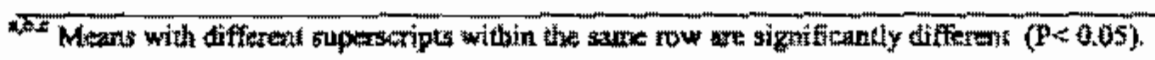


Table 3. Effects of dietary proteir and energy levels on body weight gain of the growing rabbits weaned at 26 and 35 days ages.

\begin{tabular}{|c|c|c|c|c|c|c|}
\hline \multirow[b]{3}{*}{ Dietary CP $\%$} & \multicolumn{6}{|c|}{ Weaning age, day } \\
\hline & \multicolumn{3}{|c|}{26} & \multicolumn{3}{|c|}{35} \\
\hline & 16 & 18 & 19.2 & 16 & 18 & 19.2 \\
\hline \multicolumn{7}{|l|}{ Agel day } \\
\hline $26 \cdot 30$ & $138^{8} \leq 26.19$ & $188^{2}+26$ & $197^{2} \pm 21.36$ & * & - & - \\
\hline 30.35 & $160^{b}=18.25$ & $210^{a}+10.51$ & $215^{n} \pm 20.33$ & . & - & " \\
\hline $35-42$ & $210^{*}+20.20$ & $243^{\circ} \leq 15.20$ & $224^{10}-25.77$ & $27 t^{x}=29.8 !$ & $233^{5 x}=14.9$ & $236^{x} \pm 19.83$ \\
\hline $42-49$ & $261^{b}=19.14$ & $246^{6}=17.3$ & $197^{\circ}=2138$ & $184=21.10$ & $297^{A} \pm 15.92$ & $241^{b} \pm 42.08$ \\
\hline $.49-56$ & $24 !^{2}+31.38$ & $247^{b} \pm 23.49$ & $212^{*}=29.67$ & $284^{4} \pm 25.18$ & $212^{b x}+17.33$ & $209^{*}=21.09$ \\
\hline $56 m 63$ & $232^{x} \pm 22.34$ & $220^{\circ} \pm 20.79$ & $205^{\text {ath }}=18.14$ & $215^{\text {ab }} \pm 18.30$ & $213^{\text {ab }}=16.70$ & $186^{*}=10.87$ \\
\hline 63.70 & $191^{*} \pm 29.90$ & $212^{26} \pm 25.7$ & $187^{100} \pm 21.2$ & $242^{*}+3231$ & $215 * 22.82$ & $178=21.90$ \\
\hline $70-77$ & $223^{4}+18.81$ & $236^{\#} \pm 224$ & $172^{*} \pm 12.2$ & $195^{* / 4} \pm 23.9$ & $214^{\text {at }} \pm 21.32$ & $178^{\circ} \pm 12.05$ \\
\hline 77.84 & $154^{ \pm \pm 20.92}$ & $254^{*} \pm 30.7$ & $141^{8}=16.67$ & $195^{x} \pm 27.52$ & $22^{*} \pm 12.70$ & $173^{t d} \pm 20.53$ \\
\hline \multicolumn{7}{|l|}{ Tatal gain } \\
\hline $1.26 .84 d$ & $1810^{\circ} \pm 78.12$ & $2056^{*} \pm 30.7$ & $1985^{2} \pm 16.67$ & • & - & - \\
\hline $2+35-84$ & $1512^{n}=61_{n} 30$ & $1658^{4}=25.4$ & $1338^{*}=18.53$ & $1591^{t h} \pm 27.52$ & $1607^{\circ} \neq 12.70$ & $1401^{c} \pm 20.53$ \\
\hline
\end{tabular}

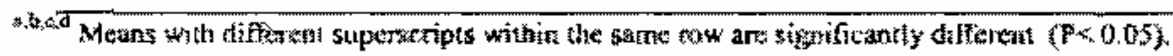


Table 4. Effects of dietary protein and energy levels on feed intake $(g)$ of the growing rabbits weaned at 26 and 35 days ages.

\begin{tabular}{|c|c|c|c|c|c|c|}
\hline \multirow[b]{3}{*}{ Detary CP\% } & \multicolumn{6}{|c|}{ Wextang age, day } \\
\hline & \multicolumn{3}{|c|}{-26} & \multicolumn{3}{|c|}{35} \\
\hline & 16 & 18 & 19.2 & I6 & 18 & 19.2 \\
\hline \multicolumn{7}{|l|}{ Aper day } \\
\hline $26-30$ & $165 \pm 7.87$ & $170 \pm 9.05$ & $186 \pm 13.13$ & - & - & . \\
\hline $30-35$ & $22 x^{12} \pm 9.26$ & $241^{* t} \pm 11.21$ & $266^{\circ}+22.14$ & - & $*$ & 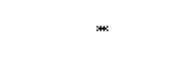 \\
\hline $35-42$ & $344^{x}+4.53$ & $408 * 9.76$ & $401^{* 1 *} \pm 11.50$ & $442^{*}+14.70$ & $382^{b x} \pm 12.7$ & $399^{6}=29.5$ \\
\hline $42-49$ & $535^{k}=2,30$ & $571^{2} \pm 12.1$ & $508^{\circ}=11.90$ & $463^{\circ} \pm 17.81$ & $463^{t}=10.4$ & $433^{5} \pm 9.59$ \\
\hline $49-56$ & $824^{*}=1.05$ & $625^{b} \pm 13.2$ & $543^{\circ}=15.35$ & $664^{3}=15.31$ & $683^{y}=6.9$ & $527^{\circ}=18.5$ \\
\hline $56-63$ & $1080^{*} \pm 13.65$ & $800^{c} \pm 10.7$ & $744^{d i} \pm 23.46$ & $690^{\circ 4} \pm 14.77$ & $929^{b}=23.25$ & $654^{d} \pm 21.65$ \\
\hline $63-70$ & $1033^{*} \pm 28.2$ & $918^{7}=9.19$ & $1035^{2} \div 23.35$ & $862^{b}=8.43$ & $832^{b}=5.80$ & $815^{*} \pm 21.44$ \\
\hline $70-77$ & $1039=18.27$ & $1064=18.82$ & $1021 \pm \$ 4.21$ & $1110=23.6$ & $1092 \pm 42.6$ & $1007 \pm 32.6$ \\
\hline 77.84 & $942^{\circ} \pm 25.25$ & $1234^{n}=31.4$ & $1046^{01} \pm 55.50$ & $1193^{*}=67.1$ & $1121^{b=1} \pm 87.3$ & $1080^{\circ}=47.9$ \\
\hline \multicolumn{7}{|l|}{ Total leed tatuke } \\
\hline $1-26-84 d$ & $6190 * \pm 83.23$ & $6031^{2}=91.4$ & $5750^{b}=55.50$ & - & 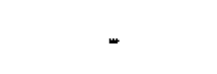 & - \\
\hline 2-35-34d & $5797^{*} \pm 88,12$ & $56200^{\prime \prime} \pm 72,4$ & $5298^{\prime \prime}=71.32$ & $5322 * \pm 98,6$ & $5502^{*} \pm 95.9$ & $4906^{x}=77.1$ \\
\hline
\end{tabular}


Table 5. Effects of detary protein and energy levels on feed conversion ratios of the growing rabbits weaned at 26 and 35 days of ages.

\begin{tabular}{|c|c|c|c|c|c|c|}
\hline \multirow[b]{3}{*}{ Diesary $\mathrm{CP} \%$} & \multicolumn{5}{|c|}{ Weaning age, day } & \\
\hline & & 26 & & & 15 & \\
\hline & 16 & Iz & 19.2 & It & 18 & 19.2 \\
\hline
\end{tabular}

Age day

$26-30$

$30-35$

$1.20^{5}=0.19 \quad 0.90^{5} \pm 0.16 \quad 0.94^{5} \pm 0.12$

$35 \cdot 42$

$1.43^{*} \pm 0.24$

$1.15^{b} \pm 0.22$

$1.24^{25} \pm 0.17$

$42-49$

$1.64^{*} \pm 0.12$

$1.68^{2} \pm 0.14$

$1.79 \div 0.04$

$1.40^{\circ}=0.21$

(

$49-56$

$2.05^{\circ} \pm 0.20$

2.32 * $\div 0.22$

$2.58^{\circ} \leq 0.21$

$2.25^{5} \pm 0.28$

$1.64^{4} \pm 0.4$

$1.65^{*} \pm 0.14$

56.63

$3.42^{*} \pm 0.18$

$2.53^{6}+0.10$

$2.56^{b}=0.16$

$2.33^{b} \pm 0.15$

$1.56^{\mathrm{d}}+0.33$

$1.79^{\star} \pm 021$

$63-70$

$4.66^{2}=0.38$

$3,64^{b}=0.3$

$3.63^{b}=0.25$

$3.21^{4} \pm 0.25$

$3.22 * \pm 0.4$

$2.52^{\text {ta }}+0.17$

$70-77$

$5.41^{k}=0.23$

$4.33^{\circ}=0.61$

$5.53^{x} \leq 0.51$

$3.56^{*} \div 0.42$

$3.46^{* x}=0.53$

$3.52^{36}=026$

$70 \cdot 77$

$4.66^{5 x} \pm 0.41$

$4.51^{\circ} \pm 0.11$

$5.94^{*} \div 0.26$

$5.69^{2} \pm 0.23$

$3.87^{\circ} \pm 0.33$

$4.58^{\circ} \pm 0.18$

$77-84$

$6.12^{*} \pm 0.41$

$4.86^{\mathrm{b}} \pm 0.44$

$6.42^{4}=0.72$

$6.12 * 0.33$

$5.10^{*} \pm 1.0 \%$

$5.66^{*} \pm 0.4$

Allover FCR

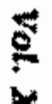

1. $26-84$

$3.41^{5} \pm 0.31$

$2.93^{*} \pm 0.27$

$2.50^{\circ} \pm 0,43$

2- 35-84

$3.83^{*} \pm 0.43$

$3.38^{\mathrm{b}} \pm 0.29$

$3.95^{\circ}=0.35$

$3,40^{b} \pm 0.23$

$3.42^{b} \pm 0.25$

$0.24^{*} \pm 0.41$

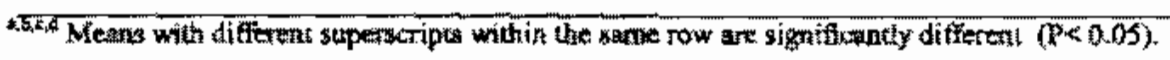


Table 6. Effects of protein and energy levels on protein efficiency ratio of the growing rabbits weaned at 26 and 35 days of ages.

\begin{tabular}{|c|c|c|c|c|c|c|}
\hline \multirow[b]{3}{*}{$\begin{array}{c}\text { Diecary protein } \\
\%\end{array}$} & \multicolumn{6}{|c|}{ Weaning age, day } \\
\hline & \multicolumn{3}{|c|}{26} & \multicolumn{3}{|c|}{35} \\
\hline & 16 & 18 & 19.2 & 16 & 18 & 19.2 \\
\hline $26-30$ & $5.27^{8} \pm 0.82$ & $6.22^{2}=0.71$ & $5.38^{8} \pm 0.60$ & 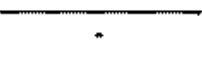 & 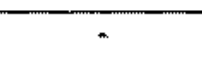 & $=$ \\
\hline 30.35 & $4.42^{*} \pm 0.16$ & $4.90^{2} \pm 0.43$ & $4.10^{6}=0.45$ & * & $*$ & * \\
\hline $3 S-42$ & $3.85^{2} \leq 0.31$ & $3.35^{3} \pm 0.23$ & $2.84^{\circ} \neq 0.32$ & $3.94^{*} \pm 0.43$ & $3.43^{b}=0.40$ & $3.07^{\circ} \neq 0.31$ \\
\hline $42-49$ & $3,08^{*}=0.26$ & $2.42^{*} \pm 0.40$ & $1.97 \pm 0.16$ & $2.51^{*}=0.21$ & $3.61^{*} \pm 0.26$ & $2.83^{b} \pm 0.20$ \\
\hline 49.56 & $1.84^{*}=0.15$ & $2.22^{6}=0.42$ & $1.58^{\mathrm{k}}=0.15$ & $2.70^{*}=0.18$ & $1.74^{t}=0.20$ & $2.01^{160} \pm 0.16$ \\
\hline $56-63$ & $1.35^{\circ}=0.18$ & $1.55^{b} \pm 0.21$ & $1.40^{k}=0.16$ & $1.97^{2}=0.20$ & $1.29^{6} \pm 0.13$ & $1.44^{5}=0.15$ \\
\hline $63-70$ & $1.17 \% \pm 0.16$ & $1.30^{b x}=0.11$ & $0.924 \pm 0.11$ & $1.77^{2} \pm 0.28$ & $1.45^{h} \pm 0.15$ & $1.11^{d} \pm 0.12$ \\
\hline 30.77 & $1.35^{h}=0.20$ & $1.25^{b}+0.15$ & $0.86^{4}=0.10$ & $1.11^{4}=0.12$ & $1.10^{*}=0.06$ & $1.54^{*} \pm 0.15$ \\
\hline $77-84$ & $1.03 *=0.18$ & $1.16^{\circ} \pm 0.14$ & $0.68^{=}=0.08$ & $1.03 * 0.10$ & $1.12^{2}=0.12$ & $0.90^{b x} \geq 0.08$ \\
\hline Total PER & $1.84^{\mathrm{k}} \pm 0.30$ & $1.92 " \pm 0.22$ & $1.55^{b} \pm 0.13$ & $1.89^{*} \pm 0.32$ & $1.64^{b} \pm 0.29$ & $1.45^{b}=0.31$ \\
\hline
\end{tabular}

ahes Means with diflerent superscripts within the kame raw are significantily different $(\mathrm{P}<0.05)$ 
Table 7. Levels of serum total protein, alburnin, total lipioss and cholesterol of the growing rabbits weaned at different ages and fed different levels of CP.

\begin{tabular}{|c|c|c|c|c|c|c|}
\hline \multirow[b]{3}{*}{ Wierary putein } & \multicolumn{5}{|c|}{ Weaning age, doy } & \\
\hline & \multicolumn{3}{|c|}{26} & \multicolumn{3}{|c|}{35} \\
\hline & $16 \%$ & $18 \%$ & 19,23 & $16 \%$ & $18 \%$ & $19.2 \%$ \\
\hline \multicolumn{7}{|l|}{ Sernan metalyolite } \\
\hline Toral protation $\mathrm{g} / \mathrm{d}$ & $5.60^{4}=0.56$ & $6.74^{2} \neq 0.55$ & $6.97^{*}=0.62$ & $5.89^{2}=0.49$ & $5.50^{b}=0.65$ & $5.77^{6} \pm 0.70$ \\
\hline Alourria, & $2.23^{6}=0.19$ & $2.38^{6}+0.92$ & $3.17^{2}=0.43$ & $2.17^{*}=0.24$ & $2.0 x^{b}+0.23$ & $2.30=0.10$ \\
\hline Cotoleteterol, mag a & $36.52^{6} \pm 4.62$ & $37.75^{5} \pm 585$ & $41.10 \mathrm{~m}=7.90$ & $45.0^{*}=2.00$ & $44.43^{4} \pm 0.25$ & $35.70^{3}=19.90$ \\
\hline Total lipid mat d! & $575.4 \pm 23$ & $178.9=51.6$ & $1892 \pm 37$. & $197,1 \pm 23.80$ & $195.9=28.55$ & $182.1=4365$ \\
\hline
\end{tabular}

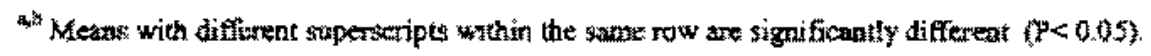


Table 8 . Effects of dietary protein and energy levels on carcass quality of the growing rabbits weaned at 26 and 35 days of ages.

\begin{tabular}{|c|c|c|c|c|c|c|}
\hline \multirow[b]{3}{*}{ Dietary protein $\%$} & \multicolumn{6}{|c|}{ Weaning age, day } \\
\hline & & 26 & & & 35 & \\
\hline & 16 & 18 & 20 & 16 & 18 & 20 \\
\hline Live weight (g) & $2123^{\circ} \div 82,5$ & $2440 \cdot 80.2$ & $2145^{*}+40 ?$ & $2525^{*} \pm 115$ & $2 \times 30^{4}=40$ & $2417.5^{4} \pm 1.7$ \\
\hline Liver weight (g) & $7153 \div 00$ & $77.5 \pm 2.5$ & $73 x+10$ & $97,3 \pm 75$ & $92.5 \pm 5.1 .3$ & $80 \times 5.10$ \\
\hline Liver \% & $3.37 \pm 0.12$ & $3.20 \pm 0.34$ & $3.43 \pm 0.29$ & $3.83 \pm 0.14$ & $3.6 \div 0.15$ & $3.3 .3 \pm 0.17$ \\
\hline kidney weight (g) & $15 \pm 0.50$ & $16.6 \pm 0.83$ & $15 \pm 190$ & $13.68 \pm 2.11$ & $17.46+2.01$ & $16.2 \pm 0.01$ \\
\hline Kidney $\%$ & $0.71 * 0.03$ & $0.68 \pm 0.04$ & $0,70 \pm 0,05$ & $0.70 \div 0.04$ & 0.60 .0 .01 & $0.67 \pm 0.03$ \\
\hline Fat weight (g) & $25 \pm 3.26$ & $32.5 \div 4.53$ & $35.6 \pm 4.40$ & $32.5 \div 12.5$ & $32.5=3.13$ & $45 \pm 3.51$ \\
\hline Fat $\%$ & i. $1.6 \pm 0.29$ & $1.39 * 0.82$ & $1.66 \pm 0.02$ & $1.23 \pm 0.64$ & $1.28 \pm 0.3 ?$ & $1.86=0.38$ \\
\hline Heart weight (g) & $7.5 \div 1.10$ & $7.5=1.2$ & $2 \pm 0.91$ & $8=0.78$ & $7.5 \pm 1.12$ & $7.5 \pm 0.64$ \\
\hline Heart \% & $0.36 * 0.11$ & $0.32=0.13$ & $0.33 \div 0.02$ & $0.33 \pm 0.02$ & $30 \pm 0.41$ & $0.30=0.09$ \\
\hline Dressed carcass (g) & $1223^{6} \neq 25$ & $1420^{2} \pm 85$ & $1242.5^{*}=83$ & $1442^{\circ}+53$ & $1422.5 * 23$ & $14225^{*} \pm 43$ \\
\hline Dressed carcass $\%$ & $57.74 \pm 1.6$ & $58.01+2.11$ & $57.86 \pm 5.01$ & $57.15=5.12$ & $34.58 \pm 422$ & $58.90=4.11$ \\
\hline
\end{tabular}

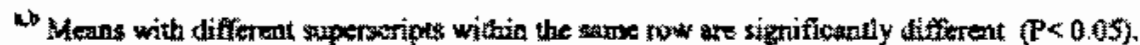


Table 9. Eftects of dietary protein and energy levels on proximate chemical composition of liver \& leg muscles of the growing rabbits weaned at 26 and 35 days of ages.

\begin{tabular}{|c|c|c|c|c|c|c|}
\hline \multirow[b]{3}{*}{ Dietary protein \% } & \multicolumn{5}{|c|}{ Weaning age, day } & \\
\hline & \multicolumn{3}{|c|}{26} & \multicolumn{3}{|c|}{35} \\
\hline & $16 \%$ & 188 & $192 \%$ & $16 \%$ & $1 \% \%$ & $19.2 \%$ \\
\hline \multicolumn{7}{|l|}{ Liver } \\
\hline Protein & $1860=327$ & $18.85 \pm 3.46$ & $18.29 \pm 2.79$ & $18.57 \pm 2.14$ & $19.1=3.46$ & $10.12+2.41$ \\
\hline Fat $\%$ & $8.75: 1.34$ & $8.40 \pm 1.48$ & $8.12 \pm 1.52$ & $7.56 \pm 1.61$ & $831+134$ & $7.80 \pm 1.03$ \\
\hline $\operatorname{Ash} 1 \%$ & $1.45 \pm 0.32$ & $1.35 \pm 0.27$ & $1.39 \cdot 0.38$ & $1.80=0.28$ & $1.65=0.22$ & $1.73 \pm 0.27$ \\
\hline Moisture & $70.2 \pm 6.21$ & 70.55 .46 & $71.8 \leq 6.47$ & $71.40=6.25$ & $70.3 \pm 6.68$ & $7.9 \pm 5.95$ \\
\hline \multicolumn{7}{|l|}{ Muscles } \\
\hline Proteia & $17.88 \pm 3.46$ & $17.75 \pm 2.38$ & $17.17+3.18$ & $17.28 \div 2.12$ & $17.22+3.18$ & $17.91=3.27$ \\
\hline Fat $\%$ & $3.6: 0.38$ & $4,60 \pm 0.67$ & $4.30 \pm 0.53$ & $3.99 \div 0.24$ & $4.37 \pm 0.51$ & $4.54 \pm 0.4$ \\
\hline Ash $\%$ & $4.16=0.32$ & $3.28 \pm 0.33$ & $4.02=0.38$ & $4.38=0.29$ & $4.18=0.24$ & $3.92 \pm 0.37$ \\
\hline Moisture \% & $74 \pm 6.47$ & $73.7 \pm 4.25$ & $73.6 \pm 7.89$ & $73.8 \div 6.47$ & $73.7 \pm 5.44$ & $73.1 \pm 3.46$ \\
\hline
\end{tabular}




\section{REFERENTCES}

Abdel Malak, N, Y, (2000) : Effect of dictary protein levels on rabblts perlormance. Eeyptian Journal of Rabblt Sclence. 10: 195206.

Allatn, C.; Poon, L. and Ckan, C. (1974) : Enzymatuc detcrmination of total senum cholesterol. Clln. Chem 20. 470.

A.O.A.C, Amociation of Offictal Analyteal Chemist (I000) : Offlctal methods of analysis. 15 th ed. Assuciation of OMcial Anatytical Chemists. Washington. D.C.

Ayyat, M. S. and Maral, 1. F. M. (1097) : Ellects of heat stress on growth, carcass tratts and blood components of New. Zealand White rabblts led vartous dietary encrgy-fiber, under Egyptian conditions. Joumal of Arld Entronments: 37:557-568.

Blas, E. and Cldonne. T. (1908): Digestion of starch and sugars. In: De Blas. J.C., Wlsennan. J. (Eds.), The Nutrttion of The Rabblt. CAr internatlonal Wallingiord. PP. 17-38.

Doumas, B. T.; Wateon, $\mathbf{W}$. A and Blags, F. O. $(\operatorname{1\theta 7} 1)$ : Albumtn standards and measurement of serum albumln whth bromocresol grcen. Ciln. Chim. Acta 31-87.

Fergueon. F. A. Lukofihr, B. D. and McNitt, J. 1. (1997) : A technical note on artficlal milk fceding of rabblt kits weaned at 14 days. World Rabbtt Science 5: 65-70.

Feuglex, A; smlt, M. N.; FortumLamothe, $L$. and Gidenne, T. (2006) : Fibre and protein requirements of early weaned rabbits and the interaction with weaning age: eflecks on digestive health and growth performance. Antmal Sclence 82 : 493 - 500 Cambridge University Prcss.

Gallots, M.: Gldenne, T. and FortwneLamothe. L. (2003) : Digestive development in the young rabbit: impact of a weaning at 21
D. In: Proc. 3rd meetings of work group 3rd and 4th cost Action 848. Prague. Cach Republic, $15 \mathrm{PP}$.

Gallola. M.: Gidenne. T.; PortuneLamothe, L.; Lo Huerouluron, 1. and Lallea, J. F. (2004) : Weaning age and developinent of the small Intestinal mucosa in the young rabblt. In Proc. Bth world Rabblt Congress. Puebla Mexico. 1079-1085.

Cldenne, $T$. and Forter-Lamothe, $L$. (2001) : Early weanlng: effect on performances and health. In: Proc. 2nd Meetings of workgroup 3rd and 4th Cost Action 848. Godollo. Hungary. $34 \mathrm{pp}$.

Gdenne, T. and Fortum-Lamothe, $L$. (2002): Feeding strategy for young rabbit around weaning: a review of digestive capaclty and nutritional needs. Anim. Sc1. 75:169184.

Gldenne, T,: Fortun-Lamothe. $I$. and lapmouse, A. (2003): Feeding behavlour of early weaned rabblt: Effect of the pellet dlameter. 10eme J. Rech. Cuntcoles Fr. 19-20 Nov., 2003 Paris, Ed. Pax G. Bnlet, ITAV Publ.. PP. 17-19.

Gldenne, T. and Fortun-Lamothe, L (2004): Growth, bealth status and digestion of rabblts weaned at 23 or 32 days of age. In: Proc, 8th World Rabblt Congress, Puebla. Mexico. 846-852.

Gongnet, G. P.; Agane. M. and Dezoumbe, D. (1093): Elfect of different protein Intake on growth performance of rabblts of local breeds. Annales de Zootechnie, 42: 75-79.

Jacoh, D. V.: Penz Junlor, A. M. and Loboute, E. M. (1902): Estect of different arnount of proleln on growth of New Zealand White rabbits. Study of galn composition and carcass evaluation. Revtsta da Sorledade 
Brastlelra de Zootecnfa, $21: 575$ - 584.

Faplan, A and kalter, A (1984); Detrenination of total serum proteln. Clin Chem the C.V. Masby Co. St Louls. Toronto. Princeton 1316-1324 and 418 .

Lebas. F. (1993): Amelinration de la vabllIte des lapereaux en cngralsaement par un sevrage tradir. Cuniculture 1 10, 73-75.

Lobee. F.; Gdenne, T.; Porez, J. M. and ueote. D. (1008): Nutrition and pathalogy. In : De Blas, J. C. Wheman, J. (Eds.), the NutrtUon of the Rabbit. CAA International, Wallingford. pp. 197-213.

Marounek, M.i Vovk, S. J. and Skrtvanova, V. (1095): Distribution of activity of hy drolytic enzymes in the digestive tract of rabbits. Brtt. J. Nutr., 73: 463-469.

KRC (1977): Nutrlent Requtrements of Rabblts. National Research Councl 2nd Ed. Wasington, D.C.

Pascual, J. J. (2001): Early weanlng of young rabblts: a revtew. World Rabblt Sci. g: 165-170.

Raharjo, Y. C.; Cheeke, P. K. and Patton. N. M. (19B6): Growth and productive performanee of rabblts on a moderately low erude proteln diet with or without methiontne or urea supplementation. Journal of Antmal Sam ence 63: 795 - 803.

Raxzorenova. E. A and Morozova, $\mathbf{K}$. $\mathbf{A}$. (1980): Nutrient requirements of rabults. Krolikovodstvo I Zverovodistwo, 5: $11-12$.

Rodri guez, J. M.; Fraga, M. J.: Pe"rez. E. and De BLas. J. C. (19B1): Influencla de la edad al destetc sobre cl crecimiento y mortail dad de los conejons durante el pertodo de cebo. In: Proceedings of the Slxth Symposlumi de Cunicultura, ASESCU, Zaragona, Spain, pp. $159-164$.

Sanchex, W. I.; Cheeke, P. R, and Pat- ton, N. M. (1085): Effect of dtetary crude protoin level on the reproductive performance and growth of New Zealand white rabults. J. Anim Sci., 60, 1029-1039.

Santoma, G.: de Blas, J. C.; Caraban"a. R. M. and Fraga, M. J. (1987); The effects of different fats and their Inclusion level in diets for growlng rabbits. Antm. Prod 45: 291 .

Senpinello, $C_{n}$ : OAdenne, $T$, and FortunLamothe, L. (1909): Digestrve capacity of the rabbit during the post-weaning perlod, ac cording to the milk/solld feed intake pattern belore weaning. Reprod. Nutr. Dev, 39: 423432.

8chlolaut. W. (198a): Present husbandry and management condluons and development trends in rabbit production. In: Proc. 4th World Rabbit Congress. Budapest. Hungary, 1. 93-112.

Bnedecor, $O$. W. and Cochran, $W, G$. (1967): Stathatlcal Methods.6th ed.. Oxford and IBN Publishting Co., PP. 344-346.

Troclna, A, Xlccato, G.; Bartorl, A and Queaque, P. I. (2001): Effect of starter diet and weaning age on growth, caccal fermentauon and body composition of young rabbits. In: Froc. 2nd Meetings of workgroup 3rd and 4th Cost Action 848. G_odollo, Hungary. 52 53.

Tumova, E., Zita L، and Stolc, L. (2000): Carcass quality is restrieted and ad lifilum fed rabblts. Czech J. Aniu. Scì., 51. 214. 219.

Xlceato, G.; Trocino, A; Sartor A. and Gueaque, P. I. (2004)r Effect of party order and Atter weanlng age on the performance and body energy balance of rabbit does. Livestock Productuon Sclence, 85: 239 - 251 .

Zanaty, G. A. and Ahmed, B, M, (2000): Effext of different dietary proteln sources and 
A. H., Orma; et al...

levets on growth performance, nutrent utilizaLon and carcass charactertstics of growing New Zealand whte rabblts. Egyptlan I. Rabbit Scl., 10(2): 265-285.
Zollner, N. and Kirach, K. (1062): Determination of the total Upid corventration in serum Zentralbatt Fur Gesamate Expertmental Medtzin 135.545.549. 
A. M., Orma; et al...

الملنصد العيبى

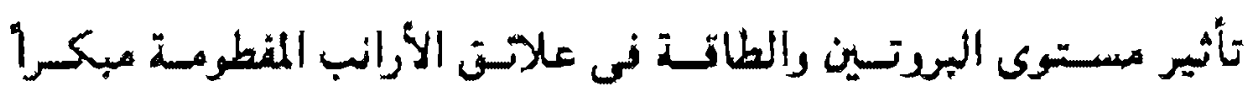

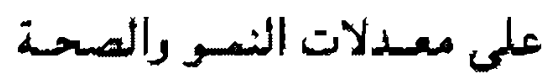

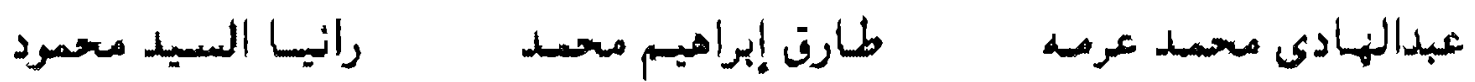

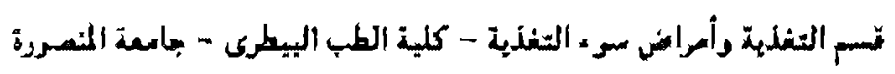

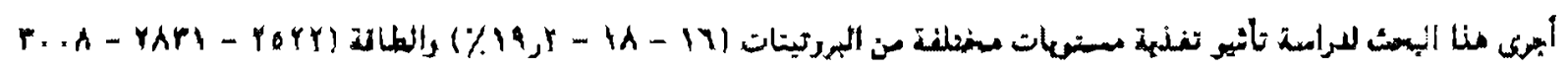

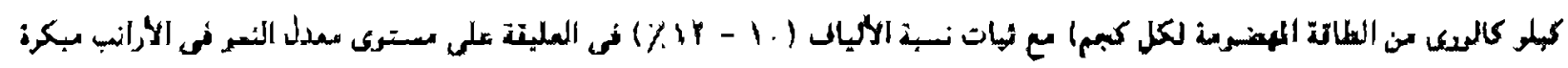

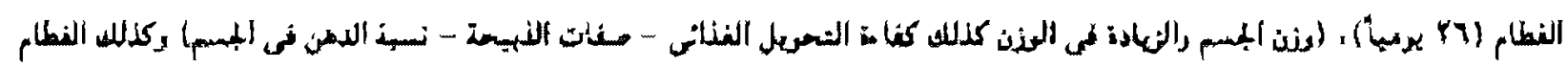

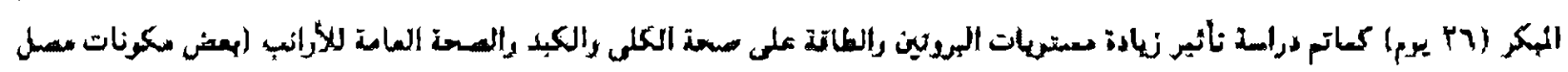

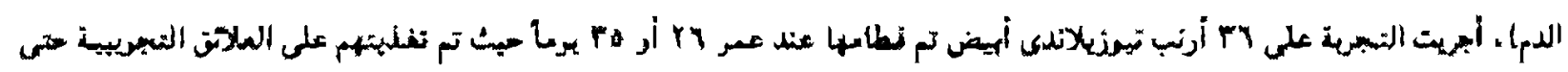

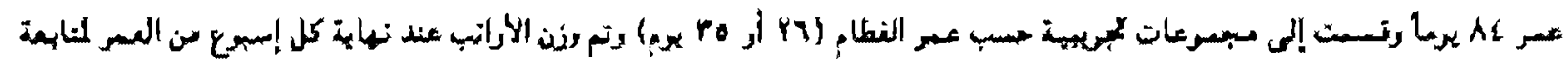

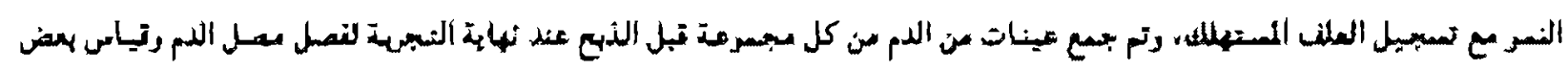

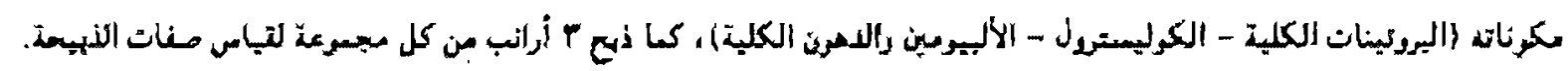

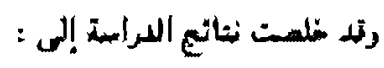

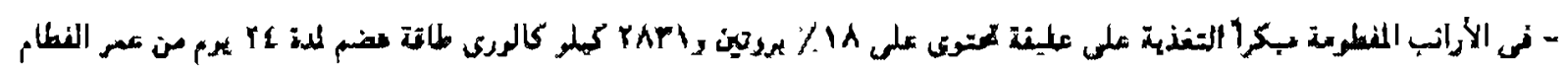

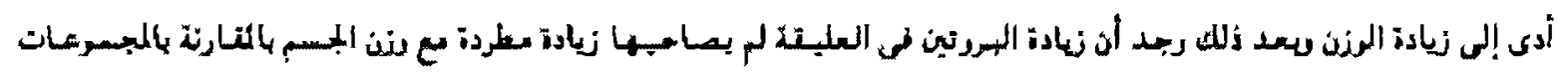
الأغخرى.

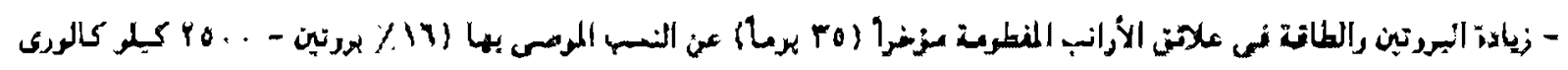

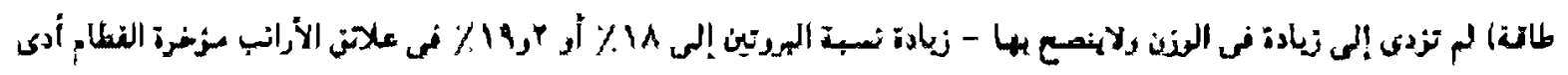

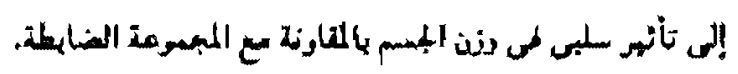

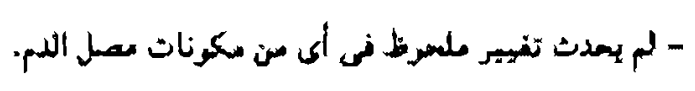

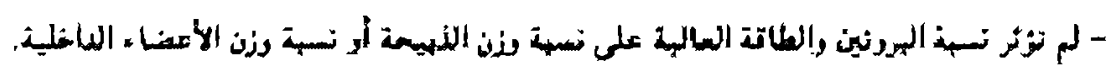

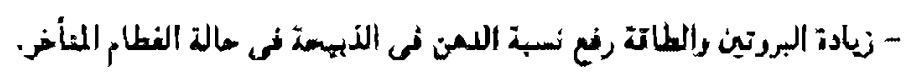

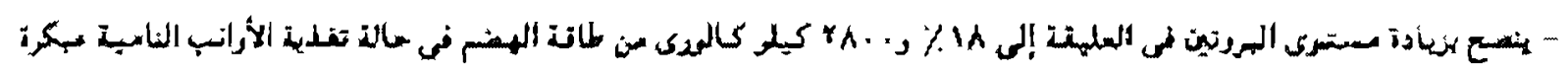

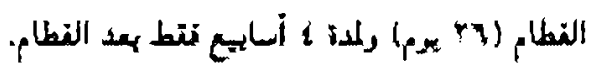

Marsoura, Vet. Med. I.

Vol. XaI, No. 1, 2010 